SÍNTESE: REVISTA DE FILOSOFIA

DECLARAÇÃO DE DIREITO AUTORAL

Os autores mantêm os direitos autorais e concedem à revista o direito de primeira publicação, com o trabalho simultaneamente licenciado sob a Creative Commons Attribution License.

Fonte:

http://www.faje.edu.br/periodicos/index.php/Sintese/about/submissions\#copyrightNotice. Acesso em: 15 jun. 2016. 


\section{ROMPENDO COM O FASCÍNIO PELO CONCEITO ABSTRATO: ALGUNS MOTIVOS PRÁTICOS E TEÓRICOS NA ELABORAÇÃo DA DIALÉTICA ESPECULATIVA}

Breaking away from the fascination exerted by the abstract concept: some practical and theoretical reasons that led to speculative dialectics

Erick Lima *

Resumo: Este artigo pretende reconstruir alguns dos motivos práticos e teóricos da dialética hegeliana. Uma introdução geral deve servir ao propósito de delinear os contornos gerais do ponto de vista da dialética especulativa, o que será tentado a partir da apropriação crítica feita por Hegel do conceito kantiano de juízo reflexionante (1). A partir disso, pretendo apresentar a versão hegeliana do projeto da "filosofia da unificação" enquanto crítica da moral kantiana (2). Em seguida, o objetivo é mostrar como Hegel antecipa, nos escritos de juventude, uma compreensão da constituição orgânica e intersubjetiva da comunidade (3). Em terceiro lugar, indicaremos como Hegel vincula a elaboração de sua noção de dialética nas linhas gerais de um diagnóstico das dificuldades de integração social na modernidade política, a serem neutralizadas pelo pensamento de uma articulação imanente entre universal e particular (4). Finalmente, pretendo concluir com uma discussão de elementos da filosofia da religião no jovem Hegel como preâmbulo da crítica à filosofia da reflexão e do nascedouro do ponto de vista dialético-especulativo (5).

Palavras-chave: Dialética, modernidade, G.W.F. Hegel, política, ética, metafísica.

Abstract: This paper intends to reconstruct some practical and theoretical issues related to the origins of Hegel's speculative dialectics. To begin with, I attempt

\footnotetext{
* Professor Adjunto do Departamento de Filosofia da Universidade de Brasília. Artigo submetido a avaliação no dia 27/05/12 e aprovado para publicação no dia 25/08/12.
} 
to delineate Hegel's dialectical point of view out of Hegel's critical appropriation of Kant's concept of reflective judgement (1). Then I present Hegel's version of the "philosophy of unification" as an attempt to criticize Kant's moral theory (2). Thirdly, I argue that Hegel anticipates, in his early writings, his organic concept of community, as well as his late theory of intersubjective mediation of individuality (3). Then I attempt to develop an interpretation of Hegel's discussion about the difficulties of social integration in political modernity, as well as about the destruction of traditional ethos by the development of market economy (4). Finally, I argue that the Philosophy of Religion in the young Hegel establishes the principles of his late critique of the "philosophies of reflection" and constitutes thereby the origin of the dialectical-speculative point of view (5).

Keywords: Dialectics, modernity, G.W.F. Hegel, politics, ethics, metaphisics.

\section{Introdução}

"A carência por compreender a lógica num sentido mais profundo do que aquele da ciência do pensar simplesmente formal é ocasionada pelo interesse da religião, do estado, do direito e da eticidade." (HEGEL, 1970, 8, 71)

$\mathrm{O}$ s textos não publicados de Hegel, produzidos entre 1796 e 1806, constituem o nascedouro de muitas concepções do sistema definitivo, como as de eticidade, de reconhecimento, e mesmo elementos da crítica ao formalismo e da lógica especulativa. Se os textos de 1802-1806 podem ser lidos, em determinados aspectos, como um processo de fermentação que resultará na concepção de sistema vinculada à Fenomenologia - e, mais tarde, à Enciclopédia -, os textos anteriores, conhecidos como "escritos teológicos de juventude", revelam, através da consideração das relações entre o "espírito do cristianismo" e os espíritos judaico e grego, os primeiros contornos de temas como a "Aufhebung do ponto de vista moral na eticidade", a constituição intersubjetiva da comunidade e a compreensão das insuficiências sócio-integradoras da modernidade política, temas vinculados à relativização do cristianismo pelo ideal da Volksreligion.

Meu objetivo aqui é reconstruir, a partir de textos de juventude como Geist des Christentums, o Systemfragment von 1800 e alguns opúsculos do período de Jena, alguns motivos práticos e teóricos diretivos na elaboração do ponto de vista adotado pela dialética especulativa, a qual constitui o âmago do projeto filosófico hegeliano, sem desprezar, contudo, a ideia de uma ruptura ${ }^{1}$ entre as orientações juvenis e tardias. Trata-se com este

\footnotetext{
1 "A ideia de um corte supõe, porém, ao mesmo tempo continuidade - e não somente a continuidade de um nexo biográfico (Lebenszusammenhang), mas também momentos de continuidade no interior do desenvolvimento do pensamento. Pois este nunca é completamente
} 
itinerário de uma tentativa de oferecer mais uma percepção no sentido daquela que $W$. Jaeschke desenvolve, a partir dos textos mencionados, sob o título de "Surgimento da Dialética e do Pensamento Fundamental do Sistema" (Entstehung der Dialektik und des systematischen Grundgedankens) (JAESCHKE, 2010, 97). Contudo, é forçoso notar que, do ponto de vista mais geral, minha posição permanece congruente com a sua e, em certo sentido, complementar. Para que o leitor possa ter condições de avaliar a pertinência desses motivos, parece-me profícuo oferecer uma caracterização geral do significado da dialética especulativa no pensamento de Hegel.

Caso se queira oferecer uma imagem geral do que se pode entender como dialética especulativa, a apresentação mais didática e geral desse ponto de vista continua sendo aquele trecho compreendido entre os parágrafos 79 e 82 da Ciência da Lógica, em sua versão presente na Enciclopédia. Entretanto, antes de culminar neste sumário, retrocedamos alguns parágrafos, especificamente à altura do parágrafo 55 do "conceito preliminar", no qual Hegel discute a noção kantiana de juízo reflexionante, já que as considerações de Kant a partir dessa noção "seriam particularmente apropriadas para introduzir a consciência no apreender e pensar da ideia concreta" (HEGEL, 1970, 8, 139). Para Hegel, através dessa noção, Kant teria "exprimido a representação, e mesmo o pensamento, da ideia" (HEGEL, 1970, 8, 139). Isso ocorre porque, segundo Hegel, a "representação de um entendimento intuitivo, de uma finalidade interna etc. ... é o universal pensado ao mesmo tempo como concreto em si mesmo. Por isso, a filosofia kantiana só se mostra especulativa nessas representações." (HEGEL, 1970, 8, 139) Ainda segundo Hegel, com ideias tais como a de belo artístico, da vitalidade (Lebendigkeit) e de harmonia entre a natureza e a liberdade, Kant teria descoberto "a saída para escapar das abstrações do entendimento separador (den Ausweg aus den Abstraktionen des trennenden Verstandes gefunden)." (HEGEL, 1970, 8, 139) Parece-me profundamente orientador perceber o ponto de vista da dialética especulativa a partir do que Hegel sustenta serem as insuficiências do modelo kantiano. A "preguiça do pensamento" (die Faulheit des Gedankens) faz com que a unidade entre o pensamento, por um lado, e a representação sensível, o sentido e a intuição, por outro, seja considerada ao modo do dever-ser (Sollen), pelo que se atém à "separação do conceito e da realidade":

"Aqui se estabelece o pensamento de uma relação do universal do entendimento para com o particular da intuição ... Mas a isso não está unido o entender de que essa relação é a verdadeira, e mesmo que é a própria verdade. Antes, essa unidade é acolhida só como vem à existência nos fenômenos finitos, e como se mostra na experiência." (HEGEL, 1970, 8, 140)

rompido por uma cesura, mas antes apenas periodizado, ou alterado em sua direção. Assim, coloca-se com a questão acerca da cesura, ao mesmo tempo, a questão pela identificação dos momentos de uma continuidade de problemas - e a questão, de grande alcance, sobre os resultados dos escritos de juventude preservados no sistema maduro." (JAESCHKE, 2010, 97/98). 
Eis por que se poderia considerar, como um reposicionamento da diferenciação kantiana entre o reflexionante e o determinante ${ }^{2}$, a indicação feita por Hegel dos três lados da lógica (a abstração, a dialética e a especulação), uma indicação "antecipada e histórica" (HEGEL, 1970, 8, 167) - ou, poder-se-ia dizer, didática e que abstrai de que se trata de "momentos do todo lógico-real, ou seja, de todo conceito e de todo verdadeiro em geral" (HEGEL, 1970, 8, 167). Enquanto o lado abstrato corresponde ao pensar como operação do entendimento (Verstand), que fixa a determinidade subsistente para si, contrapondo o universal ao particular, o conceito à intuição imediata (HEGEL, 1970, 8, 168), o momento dialético é

“a natureza própria e verdadeira das determinações do entendimento ... o ultrapassar sobre a determinidade isolada, e um relacionar dessa última pelo qual ela é posta em relação - embora sendo mantida em seu valor isolado ... constitui pois a alma motriz do progredir científico; e é o princípio pelo qual entram no conteúdo da ciência a conexão e a necessidade imanente" (HEGEL, 1970, 8, 171\172)

Ora, se tivermos em vista que Hegel denomina de "momento especulativo" justamente a apreensão (Auffassung) da positividade, do caráter afirmativo contido na passagem (Übergehen) entre as determinações isoladas em sua dissolução (Auflösung), pelo que se alcança o pensamento concreto, a "unidade de determinações diferentes" (HEGEL, 1970, 8, 176), pode-se, com ajuda da enfática diferenciação kantiana entre o reflexionante e o determinante, visualizar o ponto de vista da dialética especulativa como compreensão da gênese das determinações conceituais fixas, tanto a partir do ordenamento conceitual "prévio", imposto pretensamente desde fora ao material intuitivo, quanto a partir das demandas conceituais desse último, uma compreensão provocada de forma imanente desde os próprios modelos conceituais em questão ${ }^{3}$. Embora eu tenha de reservar a uma outra oportunidade uma elaboração mais minuciosa dessa interpretação, posso encaminhar o tema do restante desse artigo lembrando que Hegel, mesmo na forma mais amadurecida de sua apresentação do ponto de vista da dialética especulativa, ainda continua a concebê-la como sendo capaz de conduzir a racionalidade a um âmbito que, do ponto de vista

\footnotetext{
${ }^{2}$ Num contexto voltado à filosofia da história, Adorno fez uma célebre apreciação de Kant. "A incomparável grandeza de Kant comprovou-se também nisso, de que manteve com firmeza a unidade da natureza mesmo no seu uso contraditório, o dominador da natureza ... e o da faculdade do juízo, que se achega reconciliadora à natureza." (ADORNO, 1995, p. 227) Adorno acrescenta que a tensão entre o "reflexionante" e o "determinante", entre a "intuição" e o "conceito", perfaz "uma dialética do esclarecimento que o dialético por excelência, Hegel, não percebe" (ADORNO, 1995, p. 227).

${ }^{3}$ Parece-me que algumas das discussões mais gerais empreendidas na Fenomenologia ajudam a sustentar esta tese de leitura. Refiro-me, em geral, à maneira como Hegel, no prefácio, procura compreender a filosofia como superando a relação que as demais ciências estabelecem com suas proposições e conhecimentos particulares enquanto tais ciências permanecem apenas "agregados de conhecimentos" (Aggregate von Kenntnissen) (HEGEL, 1970, 3, 2).
} 
do entendimento, acaba por ter ressonâncias místicas e religiosas ${ }^{4}$. Ou, como diz Hegel em outro contexto, "essa relação é completamente de tipo especulativo. E, caso se acredite que o especulativo é algo longínquo e inapreensível (Unfassbares), só se precisa considerar o conteúdo de tal relação para se convencer da carência de fundamento (Grundlosigkeit) dessa opinião. O especulativo, ou racional e verdadeiro, consiste na unidade do conceito - ou do subjetivo - e da objetividade." (HEGEL, 1970, 10, 226)

\section{Critica da moral Kantiana}

A fecundidade da conexão estabelecida por Hegel ainda em Frankfurt entre o amor e a crítica da moral deontológica, que marca o seu distanciamento em relação a Kant (BONDELI, 1997) pela adesão à "filosofia da unificação" de Hölderlin (JAMME, 1988), surpreende pela sua atualidade 5 . Com sua reflexão sobre a religião cristã em Frankfurt, Hegel percebe que, embora seja a base da concepção moderna de justiça, a moral de herança kantiana e o direito natural legitimado a partir dela não são capazes de engendrar um tecido de relações intersubjetivas solidárias que tornem possível a combinação de um "bom viver" individual com a existência comunitária bem sucedida.

Através do conceito de amor, vinculado à discussão sobre a essência e destino do cristianismo, Hegel propõe sua primeira crítica sistemática da moralidade kantiana e da forma "jurídica" ou "legalista" da moral como tal. O tópico do "pleroma", da complementação da lei por uma motivação adequada, surgido em Berna para qualificar o esforço de Jesus em vivificar os mandamentos "mortos" do judaísmo, é retomado no contexto da reunificação dos elementos separados pela lei moral kantiana, e esta é compreendida como condensação conceitual do elemento deontológico presente no espírito do judaísmo e da lei mosaica.

\footnotetext{
4 "Deve-se notar a propósito, antes de tudo, que o místico sem dúvida é algo misterioso; contudo, só para o entendimento, e de fato simplesmente porque a identidade abstrata é o princípio do entendimento, enquanto o místico (como sinônimo do especulativo) é a unidade concreta dessas determinações que para o entendimento só valem como verdadeiro em sua separação e oposição. Se então os que reconhecem o místico como verdadeiro não vão, igualmente, além da noção de que é algo absolutamente misterioso, por sua parte, está assim declarado somente que o pensar tem para eles a significação do ato abstrato de pôr-o-idêntico ... Todo racional, por isso, pode ao mesmo tempo ser designado como místico; mas com isso somente se diz que vai além do entendimento, e de modo algum que o racional seja a considerar em geral como inacessível e inconcebível para o pensar." (HEGEL, 1970, 8, 177\178) ${ }^{5}$ Pode-se interpretar tal conexão entre crítica do universalismo deontológico e a tessitura intersubjetiva da vida comunitária como uma intensa antecipação não somente da teoria hegeliana da mediação intersubjetiva da autoconsciência, mas também de discussões recentes, principalmente no contexto do embate entre moral deontológica e as éticas valorativas fundadas na noção do "bem viver", ainda que haja, em função do "misticismo" hegeliano, enorme resistência em assumir esta filiação.
} 
Veremos aqui que, apesar da frustração final do projeto de uma Volksreligion fundada no amor, os fragmentos iniciais de Espírito do Cristianismo se nutrem da hipótese de que a religião cristã poderia, enquanto religião do amor, unificar as cisões que permeiam a vida moderna: o cristianismo, cujo destino é o mundo moderno, tem de conter a fonte, pensa Hegel, onde a reconciliação das oposições da vida moderna deve ser procurada. É neste sentido que o amor é resgatado como tentativa de estancar o individualismo que é condição da moral e do direito modernos.

A hostilidade de Abraão em relação à natureza e aos outros seres humanos corresponde à representação da onipotência de Deus que funda uma religião onde não há espaço para o amor ou unidade com o divino, mas apenas para uma relação de escravidão e senhorio entre homem e Deus (HEGEL, 1970, 1, 278), e que se reproduz na relação interpessoal baseada na legalidade (HEGEL, 1970, 1,362/363). A aproximação à moral kantiana revelará que a "positividade" inerente ao espírito judaico não pode ser corrigida em termos de rigor moral, mas antes que, tal como sua expressão mais moderna, o "legalismo moral" tem suas raízes na "cisão originária" entre sujeito e objeto e na fixação de sua oposição absoluta (DÜSING, 2004).

"À ideia de Deus dos judeus como seu senhor e quem tem autoridade sobre eles (Gebieter über sie) contrapõe Jesus a relação de Deus aos seres humanos como a de um pai para com seus filhos." (HEGEL, 1970, 1,370) Jesus pretende eliminar, segundo Hegel, o ideal judaico de um Deus onipotente e contraposto ao mundo. Esta relação homem-Deus que não é mais baseada na dominação e na subjugação, o que impossibilita o ser-um dos dois, mas uma relação de unificação e de amor, tem de assumir o lugar do ideal de um Deus supramundano. Hegel pretende mostrar que esta nova relação, na medida em que o divino é compreendido de maneira imanente à existência social, reproduz-se no universo interpessoal humano de uma forma que ultrapassa o paradigma legal-coercitivo de auto-relação e de inter-relação (HEGEL, 1970, 1,304/305).

Com efeito, a tarefa de que se incumbe Jesus é ultrapassar o destino histórico do judaísmo. Em nome disso, segundo Hegel, Jesus incorpora o ideal do "homem em sua totalidade" (HEGEL, 1970, 1,324). Jesus se teria oposto, segundo Hegel, não à lei como tal, mas sim ao que se poderia chamar de um recurso "desespiritualizado" à mesma. O que caracteriza o recurso à lei que se contrapõe ao "espírito das leis" é a exclusão mútua do dever e da inclinação, e, consequentemente, a subordinação da particularidade da natureza pulsional à universalidade do princípio estritamente racional de ação ${ }^{6}$. "Pois o mandamento do dever é uma universalidade

\footnotetext{
${ }^{6}$ Faz-se nítida a influência de Schiller. Tanto nas Über die ästhetische Erziehung des Menschen in einer Reihe von Briefen e em Über Anmut und Würde, Schiller critica Kant por ele ter deslocado a relação de dominação e escravidão para o interior do homem, exigindo virtude como "inclinação para o dever", através do que "prazer e dever são postos em conexão". Hegel radicaliza a crítica de Schiller a Kant: polemizando também a validade da lei como
} 
que permanece contraposta ao particular, e este é o oprimido quando ela domina." (HEGEL, 1970, 1,323)

A "doutrina ética" que Hegel considera estar sendo veiculada por Jesus caracteriza-se pela intenção de fornecer um complemento $(\pi \lambda \hat{\jmath} \varrho \omega \mu \alpha)$ à dominação estranha do universal abstrato da lei sobre as inclinações do indivíduo particular, um complemento pensado como retificação imanente do ponto de vista da moral kantiana, expressão, em termos de filosofia prática, do universal abstrato. $\mathrm{O}$ mesmo efeito que Jesus espera ter na crítica ao modus vivendi judaico Hegel espera ter na sua crítica àquilo a esta que é a expressão conceitual mais depurada do poder obrigante da universalidade abstrata da lei racional: a moral kantiana. Entretanto, o entusiasmo de Jesus em acabar com a unidade abstrata, coercitiva e "dominadora" entre universal e particular, como intenção de abolir a estranheza dos termos sem abolir a própria "espiritualidade" da obrigatoriedade dos mandamentos morais enquanto tal, isto é, de "complementá-la", tem de alçar-se para além da contraposição pura e simples. Ora, isto nada mais é do que subverter o significado mesmo dos termos enquanto são compreendidos de maneira apartada. "Jesus não teve simplesmente de indicar o complemento dos deveres, mas sim também o objeto destes princípios, a essência da esfera dos deveres, a fim de destruir o âmbito contraposto ao amor." (HEGEL, 1970, 1,334)

Importava a Jesus, pensa Hegel, sobretudo indicar a essência indivisa de ambos os termos, de ambas as "metades" do ser humano, não simplesmente indicar a natureza pulsional como complemento de um dever em si abstrato - o que poderia soar como a apresentação de um subterfúgio ao rigor de uma vida moral (HEGEL, 1970, 1,325/326) -, mas apresentar o conteúdo dos mesmos enquanto conteúdo particular intrinsecamente universal: a esfera desta essência, onde se dissolve a oposição entre forma e conteúdo, é o âmbito do amor, e os conteúdos que daí brotam são, enquanto tais, contrapostos à universalidade abstrata da lei. "Unicidade da inclinação com a lei, por meio do que esta perde sua forma enquanto lei. Esta concordância é o $\pi \lambda \eta ́ £ \omega \mu \alpha$ da lei." (HEGEL, 1970, 1, 326) Vê-se que, na vida ética, a concordância da universalidade com o teor da estrutura pulsional do indivíduo suspende a relação formal meramente pensada de subordinação dos interesses particulares à universalidade abstrata do dever, a relação entre determinar e ser-determinado.

Para fazer frente ao domínio ultrajante do universal sobre o singular, Jesus recorrera, pensa Hegel, a um procedimento que, ao contrário da relação determinante de "subsunção violenta" do particular sob o universal vazio do dever, faz lembrar o conceito kantiano de juízo reflexionante: a capa-

fundamento dos deveres éticos, Hegel critica, por sua vez, o princípio kantiano da eticidade como absoluto Sollen, substituindo-o pelo amor (DÜSING, 2004). 
cidade de elevação do particular até o universal, ou seja, a imanência da universalidade da obrigatoriedade em relação ao conteúdo particular dos impulsos (BONDELI, 1997). Com isso, Hegel parece estar resgatando o potencial ético da ideia da "universalidade sintética" do intelecto intuitivo de Kant e sua implícita relação orgânica da parte ao todo, ao mesmo tempo em que reinterpreta, por esta via, o mandamento cristão do amor a Deus "espiritualizado" por Jesus. "Ele [o amor] não é nenhum universal contraposto a uma particularidade, não [é] uma unidade do conceito, mas uma unidade do espírito, divindade. Amar Deus é se sentir no todo da vida sem limites, no infinito. Neste sentimento de harmonia não há, sem dúvida, qualquer universalidade; pois na harmonia o particular não é resistente, mas consoante, senão não seria nenhuma harmonia." (HEGEL, 1970, 1,363)

Mas se a universalidade e obrigatoriedade da conduta ética se erigem como inclinação ao agir ético (HEGEL, 1970, 1,301/302), revelam assim a essência unificada que é o homem tomado na totalidade de sua "natureza espiritual", o que faz ver na Übereinstimmung, na concordância, da lei e da inclinação não simplesmente a sobreposição dos termos irredutivelmente contrapostos, mas sim a enunciação discursiva de sua unidade essencial que tem de ocorrer segundo os termos fixados em sua diferença. "A concordância da inclinação com a lei é de tal espécie que lei e inclinação não são mais diversas; e a expressão concordância da inclinação com a lei se torna inteiramente inapropriada, porque nela aparecem lei e inclinação ainda como particulares, enquanto contrapostos." (HEGEL, 1970, 1,326/327)

Em suma, recorrendo a Jesus, Hegel pretende extirpar o poder da universalidade excludente e assimilar harmonicamente o particular através de uma reconstituição da ideia de universalidade como contendo o particular enquanto suspenso.

\footnotetext{
“Imediatamente voltado contra leis se mostra este espírito de Jesus, enaltecido acima da moralidade, no sermão da montanha, o qual é, na maioria dos exemplos sobre leis, uma tentativa, levada a termo, de retirar das leis o legal (das Gesetzliche), a forma de leis, e que prega não o respeito pelas mesmas, mas aquilo que as preenche e, contudo, as suspende como leis, e que é, assim, algo mais elevado do que a obediência às mesmas e que as torna prescindíveis." (HEGEL, 1970, 1,324)
}

O amor a que alude Jesus no sermão da montanha é, para falar em termos da crítica hegeliana a Kant, a conexão harmoniosa do universal da ética, o mandamento moral, e da natureza sensível do sujeito particular numa efetividade que garante a liberdade do homem "em sua totalidade". É no horizonte da plenitude viva desta relação intersubjetiva que o Hegel de Frankfurt ainda poderia cultivar esperanças de que o cristianismo pudesse superar a positividade da solidificação da comunidade em instituições e leis, o que ele, entretanto, não faz, assim como mostra sua concepção do "destino de Jesus". 


\section{Intersubjetividade e Constituição Orgânica da Comunidade}

Em contraposição à concepção "formalista" de virtude, a qual desemboca, enquanto conflito entre a eticidade e as inclinações, na dominação pelo Selbstzwang, Hegel compreende a virtude como a disposição individual para agir que surge sem dominação ou submissão. "À completa escravidão sob a lei de um senhor estranho, Jesus contrapôs não a escravidão parcial sob a própria lei, a auto-coerção da virtude kantiana, mas sim as virtudes sem dominação e sem submissão, modificações do amor." (HEGEL, 1970, 1, 359/360) Mas esta concepção de virtude somente adquire significado concreto, pela própria exemplificação proposta por Jesus, como disposição para um interagir que justamente se pauta pela não dominação do outro, isto é, pelo tratamento do outro não somente como um igual e livre, mas sobretudo como alguém para quem uma exitosa inserção social depende amplamente da participação do agente. Eis porque Hegel vê como um erro a explicitação, estabelecida na Crítica da Razão Prática e na Doutrina da Virtude, dos mandamentos cristãos que envolvem amor como fundados no respeito ${ }^{7}$. A possibilidade de se retirar destes mandamentos a própria forma do mandamento, isto é, a oposição, intrínseca ao ordenamento moral, entre o universal e o particular, baseia-se, para Hegel, no fato de que o amor não pode ser ordenado sem que sua verdadeira natureza se corrompa (BONDELI, 1997, 131). Amor é, para Hegel e "seu" Jesus, algo acima daquela oposição que caracteriza a moral, é o sentimento subjetivo e intersubjetivo da unificação, onde as leis não são mais cumpridas mais por compulsão, mas pela intenção espontânea (Geneigtheit): o amor nulifica as oposições entre o universal e o particular, sujeito e objeto, natureza e espírito e, sobretudo, entre o indivíduo e a comunidade, os quais são colocados numa relação de co-originariedade e co-pertencimento.

\footnotetext{
${ }^{7}$ Dada sua concepção de virtude como algo além do ponto de vista do embate entre razão e sensibilidade, Hegel se contrapõe sobretudo à representação do bonum supremum ou da virtude como ideal de santidade enquanto estágio moral em que se faz impossível compreender, tal como no "aperfeiçoamento moral" do sujeito, a obrigação enquanto o que possa ser praticado com satisfação. "E também a honra que ele [Kant E.C.L], em contrapartida, assegura àquela expressão de Jesus, ao considerá-la o ideal de santidade que nenhuma criatura pode alcançar, é igualmente um gasto supérfluo; pois um tal ideal, no qual os deveres fossem representados como praticados com satisfação, é em si mesmo contraditório, porque deveres exigiriam uma contraposição, ao passo que o fazer com satisfação (Gernetun) [não exigiria] nenhuma contraposição." (HEGEL, 1970, 1, 325) Acerca das sutilezas da argumentação kantiana, que já pretende contrapor à ideia de uma "coerção ao amor" uma relação entre amor e dever, bem como a uma possível antecipação da estrutura sujeito-objeto do conceito hegeliano de amor em Frankfurt a partir da concepção kantiana da "amizade moral", indicamos a leitura de Bondeli. (BONDELI, 1997, 131). Para Bondeli, Hegel aderiu à compreensão kantiana da "amizade moral" (Tugendlehre) como unificação de amor e respeito, e a reinterpretou à luz do princípio panteísta do "um em todos e todos em um", mas dirigiu-a contra Kant na forma de uma exigência de auto-superação da obrigação, querendo ver nesta relação um contra-modelo de comunidade capaz de fazer frente a um estado erigido sobre direitos e deveres.
} 
A unificação interior pelo amor supõe sua efetivação na forma de uma intersubjetividade que gera, na percepção de si no outro, o sentimento de si, que é esta harmonia entre inclinação e razão no sujeito que age. No registro comunitário, a forma da universalidade obrigante, o mandamento, revela-se como a separação completa entre eu e o próximo, a compreensão dele como algo outro que "deve" ser respeitado como pessoa ou indivíduo que é "abstratamente igual" a mim, porém, inteiramente apartado. “E ama teu próximo como a ti mesmo não significa amá-lo tanto quanto a si próprio - pois amar-se a si mesmo é uma expressão sem sentido -, mas antes ama-o como alguém que tu és. Um sentimento da vida igual, não mais poderosa, nem mais fraca. Somente através do amor é quebrado o poder do objetivo, pois através dele todo o âmbito do mesmo rui." (HEGEL, 1970, 1, 363)

É intrínseca à compreensão do dever em de amar o próximo a contrapartida de um sujeito como diversidade volitiva resistente ao mandamento, a compreensão do outro como o que "deve extorquir respeito", o significado do outro como o que é, em última instância, "objetivo", apartado, irredutível e que pode ser, nesta medida, dominado, pensado e deve ser respeitado. Mas, diz Hegel, "[U]m pensado não pode ser nenhum amado." (HEGEL, 1970, 1, 362/363). Por outro lado, o amor é justamente esta consciência da irredutibilidade redutível do outro, "ele conserva a distância entre eu e tu, a insuperabilidade do tu no eu, para ser amor" (SIEP 1979, 44); mas, sobretudo, revela-o como alguém que "eu sou", o sentimento de mim nele, o sentimento da vida igual, que não domina nem é dominada ${ }^{8}$.

A tentativa de Jesus de retirar do "ama teu próximo" o caráter de mandamento revela que no amor os indivíduos não veem no ser amado a individualidade diferente, mas antes que o "ser humano se reencontrou a si mesmo no outro." (HEGEL, 1970, 1, 394) Com efeito, por ser este "encontrar-se no outro", este ter o sentimento de si na unificação com o outro, o amor é um impulso para a unificação, para a renúncia de si e, por conseguinte, também separação, cisão da unidade originária entre as duas individualidades.

Para tematizar a articulação comunitária da unificação em Espírito do Cristianismo é necessário compreender como a unificação pelo amor se relaciona ao problema da exclusão do singular. Considerada a conexão entre o movimento de autoafirmação do indivíduo e o ponto de renúncia à individualidade, onde justamente a particularidade da natureza impulsiva

\footnotetext{
${ }^{8}$ Com lembra Ludwig Siep, segundo Hegel, a contraparte do amor, o que lhe é mais estranho, não é propriamente o ódio, onde o outro ainda vale como outro, mas antes "considerar o outro como um louco", como um pária, "o que suspende não somente toda relação com ele, mas também toda igualdade, toda comunidade da essência, o subjuga-o completamente na representação, designa-o como um nada." (HEGEL, 1970, 1, 328)
} 
entra em harmonia com o espiritual da relação, o processo social de autoposição da singularidade excludente é referido, por Hegel, à sua gênese no âmbito intersubjetivo da harmonia entre as naturezas pulsionais dos indivíduos, isto é, a um estágio originário de comunicabilidade, cooperação e compartilhamento de interesses ${ }^{9}$. Com efeito, os fenômenos que Hegel compreende como "crime" em Espírito do Cristianismo se referem a uma ruptura da unidade vital do amor, da intersubjetividade cooperativa primária a partir de onde, segundo Hegel, unicamente faz sentido algo como a individualidade excludente. A investigação deste tipo de fenômeno pode evidenciar as condições de possibilidade de retorno à vida reconciliada a partir da cisão proporcionada pela "individualização" em geral.

$\mathrm{Na}$ intersubjetividade originária do amor, prenunciam-se traços marcantes da filosofia prática de Hegel: o conceito orgânico de comunidade, a mediação intersubjetiva da consciência individual que compõe a ideia de reconhecimento e a adesão de Hegel às teses fundamentais do aristotelismo político ${ }^{10}$. Na ideia de que a contraposição traz em seu âmago a possibilidade de reunificação está prefigurada a concepção de dialética como movimento de produção da unidade através da relação dos opostos (SIEP 1979, 48).

\footnotetext{
9 Para Habermas, a causalidade do destino, pela qual ele compreende a força de restabelecimento de uma relação ética enquanto "situação não-coagida de diálogo" oprimida pela "violência" que se estabelece entre as partes, é o exemplo originário e paradigmático do que ele chama de "dialética da relação ética", a qual é, segundo ele, reconstruída por Hegel no decorrer do período de Jena sob o título de Kampf um Anerkennung. Para Habermas, esta causalidade é desencadeada pela suspensão "criminosa", isto é, individualista e excludente da relação ética originária, ou seja, da complementaridade da comunicação não coagida e da satisfação recíproca de interesses. (HABERMAS, 1974 791-792)

${ }^{10}$ Esta adesão constitui a tônica do período de Jena e, na verdade, de toda a filosofia política de Hegel, apesar da reconhecida aproximação em relação à teoria da consciência de Kant e Fichte por ocasião da Fenomenologia do Espírito. A adesão é pronunciada, sobretudo, no Naturrecthsaufsatz e no System der Sittlichkeit (LIMA, 2006, 98 e seg.). Ilting sustenta conexões interessantes capazes de indicar o teor da integração promovida por Hegel entre a filosofia política clássica e as teorias modernas do direito natural. Em primeiro lugar, segundo Ilting, o programa de um "sistema da eticidade", delineado no Naturrechtaufsatz e levado a termo, graças ao alinhamento de Hegel à Potenzenmethode de Schelling, no System der Sittlichkeit, caracteriza-se, sobretudo, por uma equiparação da doutrina espinosana da substância infinita, à qual Hegel adere imediatamente depois da Seinsmetaphysik do período de Frankfurt graças à influência do projeto schellingniano de mediação entre Kant e Espinosa, com a doutrina aristotélica da comunidade política. (ILTING, 74, 711) Para Ilting, nesta chave de leitura, três autores teriam sido significativos para Hegel. Primeiramente Maquiavel, cujas teses políticas pragmáticas incapazes de ultrapassar os limites da prudência política somente com Hobbes adquiriram fundamentação filosófica rigorosa. À incontestável influência de Hobbes nas concepções hegelianas desta fase em Jena e que se vinculam à luta por reconhecimento já se aludiu de maneira bastante consistente. (HONNETH, 1992, cap. 1) e (SIEP, 1974, 155-209)
} 
Hegel aborda, pela primeira vez, o tema da "individualização através da socialização" ${ }^{11}$ na discussão sobre o amor enquanto reconciliação do crime, isto é, da pena como destino em contraposição à experiência "legalista" da justiça como pena. "Porque, a saber, as leis são somente unificações pensadas de contrapostos, então estes conceitos não esgotam, nem de longe, o caráter multifacetado da vida." (HEGEL, 1970, 1, 347) Em Espírito do Cristianismo, "crime" 12 é uma ruptura das relações intersubjetivas primárias que possibilitam a perspectiva individual. Para além da tese enfática acerca de uma socialização prévia, Hegel confere, na sua investigação acerca do poder sócio-integrador do amor, significado filosófico aos processos formadores da modernidade política: o individualismo metodológico demanda uma teoria social de base holística.

A compreensão puramente "legalista" da pena é uma "reabsorção unilateral" do transgressor na comunidade, mesmo quando se passa da sanção à consciência da culpa. "E a pena somente executa sua dominação na medida em que a vida chegou à consciência, onde uma separação foi unificada no conceito. Contudo, sobre as relações da vida que não foram dissolvidas, sobre os lados da vida que são unificados e dados vivamente ... ela não exerce nenhuma violência." (HEGEL, 1970, 1, 347) A pena é, para Hegel, enquanto contraposição do indivíduo infrator e do universal transgredido da lei, fixada no momento da identidade abstrata ${ }^{13}$, expansão social da dominação pelo universal vazio da consciência. Assim como no embate intra-subjetivo entre universal e particular, também aqui Hegel argumenta que a identidade abstrata da unificação delito-pena deixa exterior a si o caráter variegado das relações vitais entre indivíduo e comunidade, notadamente os laços originários que estão por trás de "fenômenos" como

\footnotetext{
${ }^{11}$ Trata-se de uma tese de vasto alcance, antecipada, segundo Habermas, por Hegel. "todos os fenômenos históricos têm maior ou menor participação na estrutura dialética das relações de reconhecimento recíproco, nas quais pessoas são individualizadas pela socialização (Vergesellschaftung)." (HABERMAS, 2004) Estabelecida a conexão entre a normatividade e os processos de socialização e individualização (HABERMAS, 1974, 790/791), ele a aprofunda no sentido da relação, desenvolvida pela ética do discurso, entre a eticidade e o ponto de vista moral, ao investigar como pode ser compensada a descontextualização da moral universalista no sentido de uma vinculação da motivação racional com as atitudes empíricas eficazes, ancoradas em uma socialização individualizante (HABERMAS, 1991, 16-37). Finalmente, a vulnerabilidade da individualização pela socialização é retomada sob a perspectiva da complementaridade entre moral e direito (HABERMAS, 1997, 565).

${ }^{12}$ Para Hegel, o crime não pode ser visto simplesmente como uma transgressão da lei, mas antes como uma violação da vida em sua unicidade, dilaceramento da mesma. "A enganação do crime, que crê destruir vida estranha e ampliar a si mesmo com isso, se dissolve quando o espírito deixado para trás da vida lesada entra em cena contra o mesmo." (HEGEL, 1970, 1, 342)

${ }^{13}$ Para Hegel, a pena surge como o universal abstrato da lei totalmente apartado do particular, isto é, o universal do dever desligado da ação individual (HEGEL, 1970, 1, 340).
} 
o perdão e a reconciliação, responsáveis pela reestabilização do contexto valorativo compartilhado: a culpa pelo crime não é totalmente revogada na exterioridade da pena, permanecendo um lesão residual da vida ética, "um sentimento de impotência em face de um senhor com o qual o criminoso nada tem em comum e nada quer ter em comum." (HEGEL, 1970, 1, 345)

Em primeiro lugar, Hegel compreende a ação criminosa não como uma transgressão da lei, mas sim como violação da existência em comum, ruptura da vida ou da natureza própria (eigne Natur). “O criminoso pretendia ter a ver apenas com vida estranha, mas ele destruiu apenas sua própria vida; pois vida não é diferente de vida, porque a vida está na divindade concorde (in der einigen Gottheit). Em sua petulância, ele em verdade destruiu, mas somente o caráter amistoso da vida (die Freundlichkeit des Lebens): ele a fez se tornar um inimigo." (HEGEL, 1970, 1, 342) Com efeito, o crime, reconduzido às relações vitais rompidas por ele, pode suscitar a percepção da pena como destino, isto é, como movimento criado pelo anseio da vida cindida de voltar a ser o que era. "No destino ... o ser humano conhece sua própria vida, e seu suplicar ao mesmo não é um suplicar a um senhor, mas antes um retornar a si mesmo e um aproximar-se de si mesmo." (HEGEL, 1970, 1, 345).

Ora, se conflitos pressupõem um solo originário a partir do qual apenas podem surgir como tais, a pena sofrida pelo "criminoso" é, mais profundamente, o poder da reação da vida danificada pelo próprio ato. Com sua concepção da pena como destino, Hegel pretende justamente compreender o "fenômeno" do crime no horizonte do processo de auto-estranhamento e auto-diferenciação da vida que deságua na reconciliação da vida consigo mesma no amor. "A vida reencontrou a vida no amor. Entre pecado e sua remissão, tampouco entre pecado e pena, imiscui-se um estranho. A vida se cinde consigo mesma e se reunifica." (HEGEL, 1970, 1, 354) O estranhamento entre o universal punitivo e o transgressor é, numa perspectiva originária ${ }^{14}$, o auto-estranhamento da vida, o processo mesmo de sua auto-diferenciação. “O destino é ... incorruptível e ilimitado, tal como a vida. Ele não conhece quaisquer relações dadas, quaisquer diversidades de pontos de vista, da situação, nenhuma circunscrição da virtude." (HEGEL, 1970, 1, 347)

\footnotetext{
${ }^{14}$ É neste horizonte temático, que antecipa, ainda no registro do conceito de vida e ser da Vereinigungsphilosophie, o poder nadificante da concepção de "eticidade absoluta" no Naturrechtsaufsatz, que Hegel compreende a vida como âmbito anterior e originário do qual a lei surge como "vida incompleta", universal contraposto, incapaz de reconciliar a vida em sua beleza originária. "Mas, na pena como destino, a lei é mais tardia do que a vida e se encontra mais profundamente do que esta. Ela é apenas a lacuna da mesma, a vida falha (das mangelnde Leben) enquanto poder" (HEGEL, 1970, 1, 343/344).
} 
O destino propicia uma reconciliação do "criminoso" com a comunidade ao fazer com que o indivíduo sinta sua lesão da vida contra si mesmo, contra o outro e contra a própria vida. "O ato do criminoso não é, considerado desta maneira, nenhum fragmento. A ação que vem da vida, do todo, apresenta também o todo. O crime, que é a transgressão de uma lei, é somente um fragmento, pois fora dela [a transgressão E.C.L] está já a lei, a qual não pertence a ela. $\mathrm{O}$ crime, o qual provém da vida, expõe este todo, mas [o expõe] partido, e as partes hostis podem novamente integrar-se em um todo."(HEGEL, 1970, 1, 345) A condição "subjetiva" de possibilidade do retorno da vida a partir da cisão é a percepção pelo transgressor de seu ato como seu isolamento do todo vital, como destruição da unidade da vida, o que se fundamenta na sua defrontação com a vida que, através de seu próprio ato, se tornou hostil, isto é, com o destino; pois nesta consciência de si mesmo como inimigo ${ }^{15}$, consciência da ruptura dos laços vivos com a comunidade, da totalidade que se tornou hostil, está já contida a ideia de um impulso ao restabelecimento da unidade. "A justiça está apaziguada (befriedigt), pois o criminoso sentiu a mesma vida que ele lesou dentro de si enquanto lesada. Os aguilhões da consciência moral (Gewissen) se tornaram embotados, pois, a partir do ato, o mau espírito deles retrocedeu: não há mais nada hostil mais no homem." (HEGEL, 1970, 1, 346) Para Hegel, a "pena" se transforma em "consciência ética", isto é, na tomada de consciência pelo indivíduo da preexistência, do caráter originário dos vínculos éticos lesados por seus atos e, por conseguinte, do estado atualmente fragmentado dos mesmos. Apenas esta radicalização da "pena" como "consciência ética", o reconhecimento reflexivo pelo(s) indivíduo(s) de sua pertença originária a laços de reciprocidade e a um mundo constituído por expectativas mútuas de comportamento, apenas o reconhecimento do "crime" e da "individualização" como abstração da eticidade que a embasa, constitui a condição de possibilidade da Versöhnung, ou seja, da reparação, da reposição da intersubjetividade originária destruída pelo conflito.

O significado mais abrangente do problema da "causalidade do destino" ${ }^{16}$ reside, portanto, em que a "individualização" é pensada como realidade derivada, como acontecimento que pressupõe um todo ético marcado pela reciprocidade do reconhecimento e da satisfação dos interesses privados. Nestes termos, um ato individual que põe em xeque a integridade da vida

\footnotetext{
15 “o destino não é nada estranho ... é a consciência de si mesmo, mas [consciência de si mesmo] enquanto de um inimigo. O todo pode restabelecer dentro de si a amizade, ele pode retornar à sua vida pura através do amor: assim se torna sua consciência novamente crença em si mesmo, a intuição de si mesmo se tornou uma outra e o destino está reconciliado."(HEGEL, 1970, 1, 346)

${ }^{16}$ Para Habermas, a "causalidade do destino", a força de restabelecimento de uma relação ética desencadeada pela complementaridade da comunicação não coagida e da satisfação recíproca de interesses, é o exemplo originário da "dialética da relação ética", da Kampf um Anerkennung. Habermas a interpreta como experiência, "na relação dialógica do conhecer-se-no-outro, do fundamento comum de sua existência." (HABERMAS, 1974, 791/792)
} 
ética, representa, na verdade, sua suspensão momentânea, seu autoestranhamento, a neutralização forçada de sua validade prévia e originária. "A dinâmica do destino resulta antes da perturbação das condições de simetria e das relações recíprocas de reconhecimento de um contexto de vida constituído intersubjetivamente, do qual uma parte se isolou, alienando de si todas as outras partes da vida em comum." (HABERMAS, 2002, 43) A equação, estabelecida por Hegel em Espírito do Cristianismo e seu Destino, entre a luta como processo de "individualização" e a causalidade do destino como percepção de uma "socialização originária" bem que poderia ser tomada enquanto componente filosófico-político de uma incipiente e profícua teoria da modernização ${ }^{17}$. "A "reflexão" abandonada a si mesma deixa as totalidades orgânicas desunidas ruírem nas suas partes isoladas. Ela desfaz as relações intersubjetivas transformando-as em consequências da ação, observada reciprocamente, de atores que decidem conforme fins racionais, de tal modo que os indivíduos isolados são cortados das raízes das suas procedências comuns." (HABERMAS, 2001, 174)

\section{Destino de Jesus: amor, direito e integração social na modernidade}

Como a epígrafe desse artigo procurou sugerir, Hegel concebe a elaboração da dialética especulativa como resposta a demandas prático-teóricas historicamente criadas, as quais Hegel apreende num certo exercício de diagnóstico de época ${ }^{18}$. Tal equação tem origem em sua juventude, quando

\footnotetext{
${ }^{17}$ Fischbach atribui a Hegel a conexão da teoria do reconhecimento enquanto "teoria das condições intersubjetivas transcendentais da subjetividade", elaborada por Fichte, com a perspectiva da "luta por reconhecimento", isto é, da perspectiva da consecução deste reconhecimento a partir de árduo embate no plano de ação dos indivíduos. Habermas e Honneth reproduziriam este embate num registro "pós-metafísico" de discussão (FISCHBA$\mathrm{CH}, 1999$, 123). A "pragmática linguística universal" investigaria as normas imanentes da atividade comunicacional orientada ao entendimento mútuo. Para Honneth, embora seja a normatividade imanente do agir comunicacional que funda a possibilidade de se adotar um ponto de vista crítico sobre o que cria empecilhos à plena efetivação da interação, somente a perspectiva do "não-reconhecimento" e do "desrespeito" que embasa o ponto de vista da crítica social, a auto-compreensão dos sujeitos como parceiros na interação linguisticamente mediatizada. Eis por que o modelo de Hegel passa a servir, como conexão do desenvolvimento conflituoso dos níveis sócio-institucionais de intersubjetividade com a experiência moral da não efetivação do teor normativo do interagir social, com a "dinâmica social do desrespeito (Missachtung)", enquanto reorientação da "teoria crítica" (HONNETH, 2000). Contudo, na interpretação fornecida por Habermas para a discussão sobre a "causalidade do destino" mostra que a virada linguística na teoria crítica vem inspirada por uma experiência da negatividade da cisão na eticidade.

${ }^{18}$ Que Hegel, mesmo na maturidade, permaneça imensamente inspirado por "diagnósticos de época" orientados por motivos semelhantes, provam-no declarações como essa, que vinculam diretamente a carência de filosofia às demandas do tempo presente: "Anteriormente, não se considerava nada de ruim em pensar, pensava-se prodigamente da cabeça para fora [dela]. Pensava-se sobre Deus, sobre
} 
da sistematização filosófica de suas preocupações, momento que estamos aqui analisando. A tentativa de Jesus de tornar desnecessária, pela disseminação de uma "ética do amor", a mera legalidade, contrapartida social da ética deontológica, encontra limites no conflito entre o grau de socialização que permite e as condições de vida social numa sociedade modernizada, e não é capaz de fugir ao destino do dilaceramento.

A limitação do poder unificante do amor pelas formas jurídicas de relação intersubjetiva é a tônica dos escritos de Frankfurt e está na raiz da intuição hegeliana, alcançada finalmente em Espírito do Cristianismo, de que, . Ele compreende que em vista do desenvolvimento da modernidade política e seu reconhecimento do "direito da particularidade", da "liberdade irredutível da pessoa" - e, consequentemente, da legitimidade de um ethos universal do egoísmo -, a fraternidade e a solidariedade, preconizadas pelas comunidades cristãs primitivas, não possuem um poder sócio-integrador em condições socialmente ampliadas.

Os fragmentos que compõem Espírito do Cristianismo convergem para um resultado aporético, o qual representa, em geral, a derrocada da expectativa de Hegel quanto a uma integração social, em condições sociais "complexas" que se baseiam na garantia dos direitos individuais e salvaguarda das relações jurídico-privadas, através de uma Volksreligion vinculada ao amor. A aporia se estabelece pela mútua exclusão entre a forma genuinamente espiritual e originária de relação comunitária, definida pelo âmbito de solidariedade, confiança, fraternidade e perdão do amor, por um lado; e as relações sociais que supõem formação das individualidades, seu destacamento da unicidade vital das consciências e sua "confrontação" no horizonte da afirmação excludente da autoconsciência individual, e que são compreendidas por Hegel em geral como "relações de direito" (Rechtsverhältnisse), por outro lado (SIEP, 1979, 49).

Em sintonia com o apelo de Jesus ao despojamento das riquezas e à renúncia das posses, Hegel compreende o ambiente criado pelo destacamento das

\footnotetext{
a natureza, sobre o estado, e se tinha a convicção de que somente através de pensamentos se chegava a conhecer o que era a verdade, e não através dos sentidos, ou através de um representar e um querer-dizer (Meinen) contingentes. À medida que se pensou adiante desta maneira, resultou, contudo, que as mais elevadas relações na vida foram comprometidas por isso. Por meio do pensar foi tirada do positivo sua potência. Constituições de estado caíram vítimas do pensamento. A religião foi atacada pelo pensamento, representações religiosas firmes, as quais valiam pura e simplesmente como revelações, foram soterradas, e a antiga fé entrou em colapso em muitos ânimos ... Desta maneira, o pensamento se fez vigente na efetividade e exerceu a mais prodigiosa eficácia. Através disso, chamou-se atenção para o poder do pensar e se começou a investigar mais de perto suas reivindicações; tencionou-se, então, ter descoberto que ele [o pensar] tinha pretensões em demasia, mas não lograva realizar aquilo que empreendia ... Foi exigida do pensamento uma justificação (Rechtfertigung) acerca de seus resultados, e a investigação acerca da natureza do pensamento e da sua legitimação (Berechtigung) é o que, nos tempos modernos, tem constituído em grande parte o interesse da filosofia." (HEGEL, 1970, 8, 70)
} 
individualidades num registro que salienta o aparecimento das pessoas privadas, dotadas de direito de propriedade e de proteção à pessoa ${ }^{19}$. Para Hegel, tal institucionalização da pessoa privada traz consigo um arcabouço sócio-regulador que forma um "tecido de legalidades" (Gewebe der Gesetzlichkeiten) (HEGEL, 1970, 1, 401), uma multiplicidade de direitos que tornam obsoletas as virtudes genuinamente intersubjetivas enquanto "modificações do amor", e privilegiam um agir "ético" ou "virtuoso" baseado na "exclusão", entendida aqui no horizonte do processo de formação de individualidades mutuamente excludentes (HEGEL, 1970, 1, 334).

Diante desta relação intersubjetiva sob a égide do paradigma da justiça, uma relação mutuamente excludente cuja finalidade é estabelecer o ponto de vista reciprocamente reconhecido da igualdade do direito de ambos, a posição de Hegel com respeito ao amor é difícil de se caracterizar. Por um lado, diz Hegel, "no amor o ser humano se reencontrou a si mesmo no outro. Porque ele é uma unificação da vida, pressupunha a separação, um desenvolvimento, uma multilateralidade formada da mesma." (HEGEL, 1970, 1, 394/395) Entretanto, a este reconhecimento de que o amor pressupõe, enquanto unificação da vida, a separação e a formação (Bildung) dos elementos cindidos, se contrapõe a percepção mais ou menos clara de que, sob determinadas circunstâncias sociais, o amor não é capaz de nulificar todas as cisões operadas na substancialidade vital pela individualização, mas se torna excludente em relação a determinadas formas de vida: “Quanto mais ampliadas em multiplicidade são as relações e os sentimentos dos que se amam, quanto mais interiormente o amor se concentra, tanto mais excludente ele é, tanto mais indiferente [ele é] a outras formas de vida." (HEGEL, 1970, 1, 394/395)

Para Hegel, a ampliação do alcance da unificação tem a tendência de não abarcar o todo da vida social, mas passa a se comportar de maneira excludente com relação a uma individualização socialmente sistemática. Indiferente a um emaranhado de relações que cindem a unidade vital pelo destacamento das individualidades, parece restar ao amor somente a "efetivação localizada" no interior de círculos restritos de indivíduos numa completa sintonia de atitudes, indivíduos, poder-se-ia dizer, que participam do mesmo ethos. "Através da ampliação do amor a uma comunidade inteira, resulta do no caráter do mesmo que ela não é uma unificação viva das individualidades, mas antes que a fruição do mesmo se limita à consciência recíproca de que elas se amam." (HEGEL, 1970, 1, 405)

\footnotetext{
${ }^{19}$ Ao utilizar o conceito de Bildung para se referir ao processo de condensação da individualidade destacada da eticidade substancial, Hegel parece compreender este processo como contendo mais elementos do que aqueles que convergem para a origem do Privatmensch a partir do declínio da pólis antiga, o que corresponde, nos contornos gerais, à tese de Lukács sobre os escritos de Frankfurt (LUKÁCS, 1986). Para Lukács, somente no período de Frankfurt aparece para Hegel o problema de uma avaliação positiva das instituições modernas, da sociedade burguesa e do indivíduo privado.
} 
A questão não é para Hegel nada trivial: sobre a possibilidade de uma integração socialmente abrangente pelo princípio do amor se baseia sua expectativa quanto à restauração da beleza de uma "religião do povo" (HEGEL, 1970, 1, 394). Diante da bela ideia de um povo de Deus, Hegel constata, entretanto, que a integração social abrangente tem que se basear em outros elementos, os quais concebe já em certa sintonia com o que se tornará, posteriormente, o "sistema de carências" (HEGEL, 1970, 1, 395). Hegel parece com isso investir o paradigma jurídico-moral da justiça e do respeito recíproco à intangibilidade da pessoa, de um papel extremamente significativo na manutenção de uma comunidade abrangente. “Um círculo do amor, um círculo de espíritos (Gemütern) que renunciam, um em face do outro, a seus direitos a tudo de particular e são somente unificados pela crença comunitária e esperança, cujos fruir e alegria são somente esta unanimidade pura do amor, é um pequeno reino de Deus." (HEGEL, 1970, 1, 407).

Amor e direito, unidade e multiplicidade, identidade e diferença, enquanto formas paradigmáticas de intersubjetividade, são compreendidos como opostos irreconciliáveis que possuem, todavia, um ponto em comum: ambos se revelam inadequados enquanto princípios absolutizados da integração social. Padecendo da positividade geral do legalismo, o direito se caracteriza, enquanto relação intersubjetiva, pela consideração do outro como separado, como objeto apartado ainda que intangível segundo a lei. Por outro lado, para o amor, o obstáculo nada mais é do que a formação lato sensu da individualidade. "A alegria dele [do amor E. L] se mescla com toda outra vida, reconhece-a, mas se recolhe ao ter o sentimento de uma individualidade" (HEGEL, 1970, 1, 395).

A insuficiência sócio-integradora do amor se mostra na necessidade de se recolher a um círculo de "ethos único" como forma de encontrar a satisfação que é seu estado de harmonia intersubjetiva e de unicidade da consciência. Eis, portanto, o diagnóstico hegeliano quanto à insuficiência do amor enquanto princípio sócio-integrador e, por conseguinte, da inépcia do cristianismo como "religião pública": "um amor entre muitos permite, portanto, apenas um determinado grau da força, da interioridade e exige igualdade do espírito, do interesse, das muitas relações de vida, esmorecimento das individualidades." (HEGEL, 1970, 1, 395) As relações de amor e fraternidade do séquito de Jesus não possuem a "objetividade" do encontro de si no outro, da superação da exclusão recíproca dos indivíduos, mas permanecem um sentimento "subjetivo" da unidade pura apartada do mundo. Com efeito, a plenitude da vida não é experienciada na forma de uma existência comunitária, na forma de uma vida comunitária que é capaz de se sobrepor às cisões decorrentes da individualização, mas tem de se satisfazer com uma efetivação sectária. É este sectarismo que, ao fim e ao cabo, torna o cristianismo inapto a oferecer uma integração social sob o ethos único do princípio do amor ao próximo e da reconciliação: 
“o amor deles [do círculo de espíritos que é um pequeno reino de Deus] não é religião; pois unicidade, o amor dos seres humanos não adquire, ao mesmo tempo, a apresentação desta unicidade. Amor os unifica, mas os que amam não conhecem esta unificação. Onde eles conhecem, conhecem o apartado (Abgesondertes)." (HEGEL, 1970, 1,407)

No comportamento dos discípulos diretos de Jesus se prefigura o desenvolvimento do cristianismo que deságua na separação entre igreja e estado. $\mathrm{O}$ amor fraterno dos primeiros cristãos, uma relação comunitária que somente se realiza em sua pureza graças ao destacamento do mundo social, pode, enquanto sentimento, ser exprimido pela interioridade fervorosa em suas ações religiosas e na proclamação de sua fé, mas não em manifestações da vida que se caracterizam pela cisão de sua unidade originária, isto é, "fenômenos" da vida que justamente caracterizam a modernidade política.

Ao pretender estar acima das relações naturais e das ações "excludentes", sem ter se reconciliado com elas, o amor dos primeiros cristãos, baluarte espiritual do cristianismo, tem de permanecer socialmente inefetivo e sem a força vital que possibilite sua reconciliação com as relações sociais petrificadas. Como o estado não pôde ser superado, reconciliado com a vida no amor, "permanece o destino de Jesus e da sua comunidade ... uma perda de liberdade, uma limitação da vida, uma passividade na dominação por um poder estranho" (HEGEL, 1970, 1,399). Para Hegel, na medida em que, apartada do mundo, a união cristã se reproduz apenas pela dependência em relação ao mestre que lhes conferiu a fé, o cristianismo se torna, no âmago de sua doutrina, uma religião positiva, uma religião da dependência na qual não se alcança a unidade da vida que é a imanência do divino, mas o divino tem de permanecer um objeto da consciência.

É certo que o fracasso do projeto hegeliano da Volksreligion, da religião pública, construído sobre a tradição marcante para Hegel da Vereinigungsphilosophie, da filosofia da unificação, não representa apenas a derrocada do ideal de juventude, mas sim o marco para o revigoramento de suas posições com relação à filosofia social e o impulso para a construção do seu sistema da eticidade a partir de Jena: Hegel verá como problema principal de sua teoria da eticidade a integração de relações intersubjetivas limitativas, as quais constituem o paradigma jurídico-moral do respeito recíproco e respondem também pela autoafirmação da individualidade sob as condições de uma socialização que se processa com o advento da economia capitalista; e relações éticas solidárias, responsáveis por uma socialização positiva e pela formação de aspectos da personalidade que somente ganham seu sentido pleno no não isolamento e no "direito" da natureza pulsional estabelecido pela mediação do outro. 


\section{Critica da Filosofia da Reflexão e a Religião como acesso ao absoluto: o nascimento da dialética especulativa entre Frankfurt e Jena}

Antes de desenvolver sua concepção madura acerca da relação entre filosofia e religião, segundo a qual a religião consiste numa dimensão espiritual de mesmo conteúdo da filosofia, ainda que apresentada de forma conceitualmente insuficiente, Hegel havia aderido, nos "Escritos Teológicos de Juventude", a uma tese substancialmente diferente, a saber: a religião como plena efetivação da filosofia. Nesta época, fortemente influenciado pelo "misticismo romântico" radicalizado por Hölderlin, Hegel considerava a superioridade da religião frente à filosofia sob a perspectiva de sua capacidade de manifestar uma verdade ontológica inacessível à reflexão, refratária, portanto, à linguagem proveniente de uma matriz lógico-formal, aguçada pelo subjetivismo moderno. Hegel herda, assim, no que concerne a uma compreensão da experiência religiosa, o tema romântico da inefabilidade do ser, da indizibilidade do sagrado. Este tema é vital para o pensamento de Hegel, principalmente se se tem em vista que Hegel é por este motivo conduzido a conceber uma forma alternativa e complementar de racionalidade, à qual confere o nome de dialética especulativa, capaz de acessar o "nexo ontológico" resistente ao formalismo.

Embora tenha chegado a nós de maneira fragmentária, o Systemfragment de 1800 documenta um marco no desenvolvimento intelectual de Hegel. Último texto escrito em Frankfurt, quando se encerra a habitualmente denominada orientação teológica, e imediatamente anterior ao frutífero período de Jena, onde o ideal da totalidade imanente se articula especulativamente, o Systemfragment, concluído em 14 de Setembro de 1800, parece materializar, do ponto de vista teórico e cronológico, a promissora hesitação que Hegel transmite a Schelling na célebre carta de 2 de Novembro do mesmo ano. "Em minha formação científica, que se iniciou pelas necessidades subordinadas do ser humano, tive de ser impelido em direção à ciência, e o ideal de minha juventude teve de tomar a forma de reflexão, transformar-se, ao mesmo tempo, em um sistema." (HEGEL, 1952, 59)

O título "Fragmento de um Sistema de 1800" foi atribuído ao texto por Herman Nohl, discípulo de Wilhelm Dilthey, no contexto de sua compilação de textos de Hegel anteriores à sua primeira publicação em vida, a Differenzschrift. Nohl deu à sua edição o título de Hegels Theologische Jugendschriften, título que, certamente, constitui uma brutal redução do escopo temático destes escritos de Hegel, os quais se voltam não somente para questões de teologia bíblica, mas, sobretudo, para a filosofia da religião, a moral, a política e até mesmo para problemas "especulativos". De certa forma, o Systemfragment representa o momento-chave do pensamento do jovem Hegel em que há um certo deslocamento das preocupações 
político-religiosas pela necessidade, sentida como premente, de elaboração de um sistema filosófico (SIEP, 2000, 24). Entretanto, o Systemfragment se revela também como um interessante reflexo da amplitude temática das "experimentações" do jovem Hegel.

Se o texto prenuncia, nos umbrais da autonomização do linguajar hegeliano, ainda marcado pelas investigações histórico-religiosas, a articulação especulativa da noção de totalidade, revela também, por outro lado, uma atitude bastante sóbria em relação à filosofia da reflexão, cuja forma paradigmática remonta, para Hegel, a Kant e sua separação metodológica entre sujeito e objeto.

O estudo do Systemfragment pode corroborar facilmente a posição de Bourgeois segundo a qual tal texto prepara dois temas posteriores fundamentais. $\mathrm{Na}$ medida em que leva a reflexão a negar a si própria, o texto de Hegel concebe a autorreferencialidade da negação; em segundo lugar, inextricavelmente ligado ao que se convencionou chamar de "crise de Frankfurt", é visível no Systemfragment, especialmente na noção de "unificação com o tempo", mencionada em seu parágrafo final, a ruptura com a idealização da totalidade viva, o que constitui o autêntico nascedouro da compreensão de que ideia e realidade se constituem como momentos organicamente, intrinsecamente, ligados, em movimento incessante de tensão e unificação. Trata-se aqui não somente da elaboração do emblemático enunciado especulativo da unidade entre ser e pensar, de que Hegel se ocupa já na Differenzschrift, mas também da racionalidade imanente ao desenvolvimento histórico, a qual desempenha, já em Glauben und Wissen, papel inconteste na percepção hegeliana da modernidade. Para compreender, ao menos em termos gerais, o lugar ocupado pelo Systemfragment no itinerário hegeliano, façamos um rápido mapeamento da transição de Frankfurt a Jena.

Os fragmentos de Frankfurt empreendem a ruptura de Hegel com as decorrências teológico-morais da filosofia de Kant. Até o fim da década de 1790, em Tübingen e Berna, apesar do debate especulativo em torno das supostas incompletudes da filosofia crítica, Hegel se atém ainda à compreensão da religião cristã "nos limites da simples razão", nutrindo a expectativa de que a "filtragem" racional dos elementos positivos do cristianismo pudesse contribuir para um revigoramento da vida comunitária, na forma de um resgate da imediatez da vida política antiga em face do dilaceramento da unidade ética ocasionada pela hipertrofia da vida privada. No quadro desta possível transformação política pela difusão pública de uma religião fundada na moral da autonomia, é justamente tal padrão racional da Volksreligion que leva Hegel a perceber a degeneração do cristianismo em uma religião positiva, guiada por preceitos que não podem se coadunar com a concepção de liberdade a que a moral kantiana alçara o Zeitgeist. Tais resultados se expressam nas duas maiores obras do período de Berna: Fragmente über Volksreligion und Christentum (1793-1796) e Die Positivität der christlichen Religion (1795/96). 
Entretanto, compreender o jovem Hegel em Frankfurt e Jena exige a percepção da confluência entre as "investigações religiosas" e o panorama filosófico pós-kantiano. Hölderlin e Schelling, companheiros do Tübinger Stift, ocupavam-se mais entusiasticamente com questões de ontologia e filosofia transcendental, no sulco da publicação, em 1794, da Grundlage de Fichte. É apenas em Frankfurt que Hegel se embrenha no universo temático criado pelo problema do "fundamento de unidade do suprassensível" (KANT, 1968, V, BXX), o que acontece sob a orientação de uma mediação entre Kant e Espinosa, por um lado, e do ideário da Vereinigung, por outro. Fichte já havia assimilado o problema da dicotomia entre liberdade e natureza na sua doutrina da gênese das faculdades prática e teórica da razão pelo processo de determinação recíproca do eu e do não-eu. Com isso, torna-se possível a Hegel - já em Glauben und Sein, parte final dos Entwürfe über Religion und Liebe, de 1798 - a articulação da concepção de Vereinigung em termos da suspensão da separação entre sujeito e objeto. Seguindo a crítica de Hölderlin a Fichte, Hegel compreende a Vereinigung como "harmonia ou unificação" originária dos contrapostos. Entretanto, por ter sido conduzido à especulação por preocupações sócio-filosóficas,

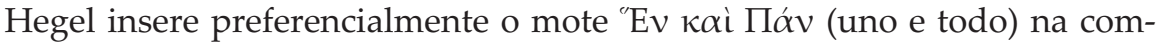
preensão da unidade ética autêntica do amor, da unificação do indivíduo com a natureza e com a comunidade, o que não impede, como mostrará o Systemfragment, o direcionamento da Vereinigung a uma crítica especulativa das filosofias do dualismo, calcadas no entendimento.

O amor é a unidade bipolar em que há ausência completa de dominação, em que sujeito e objeto em sentido tradicional não mais estão presentes e se ultrapassa o subjetivismo e objetivismo absolutos das sínteses prática e teórica. "Aquela unificação pode ser denominada unificação do sujeito e do objeto, da liberdade e da natureza, do efetivo e do possível. Se o sujeito conserva a forma do sujeito, e o objeto a forma do objeto, a natureza [permanece] sempre natureza, então nenhuma unificação é encontrada. $O$ sujeito, o ser livre, é o que prepondera, e o objeto, a natureza, é o subjugado" (HEGEL, 1970,1, 242) É a crítica de Hölderlin a Fichte que é determinante para a refutação de um ideal de subjetividade prática incondicionada que, a partir do aquém da efetividade consciente, deve se alçar à infinitude pela paulatina aniquilação de toda a objetividade, de maneira que se pode reconduzir a unificação da natureza e da liberdade, onde objeto e sujeito são um só sem subordinação, à concepção do Sein explorada por Hölderlin em sua obra-prima Urteil und Sein de 1795 (JAMME, 1988, 1990). Entretanto, ao contrário de Hölderlin (WYLLEMAN, 1986), que encontra na "intuição intelectual" do ser o acesso à infinitude, Hegel compreende que a unificação é experimentada no sentimento amoroso.

Um aspecto da adesão de Hegel ao ideário da Vereinigungsphilosophie, da filosofia da unificação, visível em sua crítica da moral deontológica pela unificação entre dever e inclinação no sentimento do amor, é importante 
para a compreensão da crítica à filosofia da reflexão que começa a se delinear no Systemfragment, em forte conexão com uma instigante tese acerca da experiência religiosa: a insuficiência do pensamento discursivo e a inefabilidade da unificação absoluta. No projeto de Hegel em Frankfurt são empregadas, em conexão com a ideia de experiência religiosa, noções que prefiguram a lógica especulativa. Hegel introduz, por exemplo, a noção de "não-conceitualidade" da suspensão da oposição entre universal e particular, segundo a qual a eticidade, concebida em unidade harmoniosa com a inclinação sensível, não está, como de costume, contraposta, enquanto universal abstrato, ao particular, ao sujeito natural que sente a inclinação e realiza as ações.

“Este poderia ser o primeiro projeto, ainda rudimentar, de uma universalidade não abstrata ou discursiva, mas concreta, a qual posteriormente Hegel vai desenvolver ... em sua lógica especulativa ... Nos escritos de Frankfurt, aquela unidade de razão e sensibilidade, de eticidade e inclinação é, enquanto amor, um sentimento fundamental que não pode ser determinado em si mesmo conceitualmente." (DÜSING, 2004, 4)

Este caráter inefável da unificação viva (BONDELI, 1997), que se conecta com a posição mantida até Jena de que o pensamento conceitual e discursivo, isto é, a reflexão, é incapaz de exprimir o "ser" anterior à Ur-teilung, chega a se insinuar nos ensinamentos de Jesus, que, ao tencionar retirar a forma legal dos mandamentos éticos durante o sermão da montanha, parece ser presa destas armadilhas do pensamento conceitual.

“Quando Jesus exprime também aquilo que ele contrapõe às leis e [que põe] acima delas enquanto mandamentos ... então esta expressão é mandamento em um sentido inteiramente diferente do que o dever-ser do mandamento do dever (das Sollen des Pflichtgebots). Ela é somente a consequência de que o vivo é pensado, exprimido, dado na forma que lhe é estranha do conceito, enquanto, em contrapartida, o mandamento do dever, segundo sua essência, é, enquanto um universal, um conceito." (HEGEL, 1970, 1, 324)

Hegel associa claramente à crítica da moral deontológica a resistência do amor frente à intenção reflexiva de fornecer acesso discursivo ao "uno", compreendido na esteira do "ser" de Hölderlin, cujo acesso privilegiado é, para o Hegel de Frankfurt, ainda a experiência religiosa ${ }^{20}$. "O Systemfrag-

\footnotetext{
${ }^{20}$ Uma maneira de ver como Hegel se distancia, graças à consecução do ponto de vista da dialética especulativa, do tema da inefabilidade do absoluto, consiste em lançar um olhar nas linhas gerais da relação entre dialética e linguagem a partir da Fenomenologia. Hegel adere, em geral, a uma compreensão de linguagem refratária a tendências esotéricas e solipsistas ocasionadas pela indizibilidade: "Enquanto a linguagem é a obra do pensamento (das Werk des Gedankens), também nela nada se pode dizer que não seja universal. O que eu apenas viso (meine) é meu (mein), pertence-me enquanto a este indivíduo particular; mas, se a linguagem só expressa o universal, eu não posso dizer o que apenas viso. E o indizivel (das Unsagbare) - sentimento, sensação - não é o mais excelente, o mais verdadeiro; e sim o mais insignificante, o mais inverídico (das Unbedeutendste, Unwahrste)." (HEGEL, $1970,8,70)$ Eis por que talvez não configure surpresa se Hegel sustenta, com respeito à relação entre lógica dialético-especulativa, a seguinte tese: "Acredita-se habitualmente que o absoluto deve
} 
ment de Frankfurt é assim a elaboração reflexiva, já bastante técnica, da autocrítica da reflexão filosófica, afirmando que só a religião, o outro da filosofia, poderia levá-la a termo, em sua infinitude, em sua totalidade." (BOURGEOIS, 1994, 388) Notório é que a resistência à discursividade se associa, antes do Systemfragment, à impossibilidade de o amor ser enunciado como um princípio prático, acarretando sua fixação no momento conceitual da universalidade. "Estas formulações mostram, de fato, uma luta de Hegel com a linguagem, a qual lembra o pensamento místico, a saber: ter de apreender ainda linguisticamente aquilo que deve repousar para além de todas as fixações da linguagem e do pensamento." (JAESCHKE, 2010, 93)

“É uma espécie de desonra ao amor se ele é ordenado, que ele, um vivo, um espírito, seja chamado por nome. Seu nome, que sobre ele se reflete, e o pronunciar do mesmo não é espírito, não [é] sua essência, mas antes contraposto a ele, e somente enquanto nome, enquanto palavra ela pode ser ordenada." (HEGEL, 1970, 1, 363)

O abismo que separa o conceito frankfurtiano de Vereinigung do ponto de vista especulativo da crítica às oposições engendradas pelo entendimento, que é deflagrado em Jena e segue até as últimas obras, fica claro no Systemfragment, onde tal conceito é discutido também em conexão com o conceito de vida, mas no horizonte, abandonado por Hegel em Jena, do acesso à suprema unificação através da religião.

"A elevação do finito ao infinito caracteriza-se, como elevação da vida finita à infinita, enquanto religião, justamente por meio disso: que ela não põe o ser do infinito como um ser pela reflexão, como um objetivo ou subjetivo, de tal maneira [, portanto,] que ela acrescenta ao limitado aquilo que o limita." (HEGEL, 1970,1, 423)

É ainda à religião que Hegel delega o "poder de unificação" do indivíduo com a vida absoluta. Religião é a forma mais elevada de unificação entre razão e natureza, entre indivíduo e comunidade. Mas mesmo esta "primazia" da religião não é totalmente apartada da concepção "jenense", pois a incapacidade do pensamento discursivo em alcançar por si só a unificação se deve ainda ao caráter incontornável das oposições geradas pelo enten-

estar situado muito além; mas ele é justamente o que está de todo presente (das ganz Gegenwärtige), mesmo sem consciência expressa disso, sempre levamos conosco e utilizamos. Tais determinações-de-pensamento (Denkbestimmungen) estão sempre depositadas (niedergelegt), sobretudo, na linguagem ... as noções lógicas (Die logischen Gedanken), entretanto, não são nenhum somente em relação a qualquer outro conteúdo; mas qualquer outro conteúdo é apenas um somente em relação às noções lógicas." (HEGEL, 1970, 8, 84) A propósito, tais considerações são muito mais próximas do tópico, desenvolvido na Fenomenologia, da contraposição entre a noção apofântica da proposição e sua estrutura propriamente especulativa, o "conflito da forma de uma proposição em geral e da unidade do

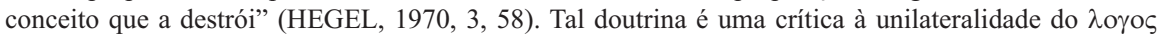
$\alpha \pi \circ \phi \alpha \nu \tau \iota \kappa о \varsigma$ e, neste sentido, o acesso a uma forma menos unilateral de racionalidade: "apenas aquela exposição filosófica lograria ser plástica [, a saber ]: a que excluísse estritamente a forma da relação costumeira das partes da proposição.” (HEGEL, 1970, 3, 59) 
dimento. A própria vida somente é pensada como conceito limitado pelo seu contrário. Nesta tese está a raiz da enunciação da vida que, segundo Hegel, é possível ao pensamento: "Eu precisaria me exprimir [de maneira a dizer que] a vida é a ligação da ligação e da não-ligação." (HEGEL, 1970,1, 422) "Mas também essa complexa fórmula [da ligação (Verbindung) da contraposição (Entgegensetzung) e da relação (Beziehung)] não vale aqui para Hegel como solução conceitual satisfatória, mas antes simplesmente como índice do caráter inapropriado da reflexão e, por isso, ele escolhe o subjuntivo para introduzi-la." (JAESCHKE, 2010, 92) Tal "princípio", na medida em que não deixa derivar a antítese da síntese, a não-ligação da ligação, enquanto resultado de uma reflexão que diferencia, continua sempre a excluir de si seu contrário: "toda expressão é produto da reflexão e, portanto, pode ser mostrada cada uma como um posto, de maneira que sendo posto algo, ao mesmo tempo um outro não é posto, é excluído." (HEGEL, 1970,1, 422) Esta insuficiência da reflexão pode ser eliminada, segundo Hegel, se se considera a "ligação da síntese e da antítese" (HEGEL, 1970,1, 422) não como "um posto, compreendido (Verständiges), refletido", mas como "um ser exterior à reflexão." (HEGEL, 1970,1, 422)

A alternativa encontrada por Hegel é a "compreensão não conceitual" da ligação e da não-ligação como diferenciações de um "ser" exterior à reflexão e que a abarca numa totalidade ${ }^{21}$, em conexão com seu contrário. Portanto, na falta de alternativa que pudesse conceituar este nexo - pois conceituar é, para Hegel, precisamente refletir e diferenciar e, com efeito, diferenciar o pensar do seu pensado -, não resta outra possibilidade a não ser considerar que este ser anterior à reflexão somente pode ser vivido nas ações religiosas de unificação com Deus. Como a filosofia - e entenda-se aqui, sobretudo, a filosofia da reflexão - somente pode enunciar este "ser", e cabe à experiência religiosa o preenchimento de sua plena vivência, a filosofia, diz Hegel, "tem justamente por isso de terminar com a religião, pois aquela é um pensar e, portanto, tem um oposto em parte do não-pensar, em parte do pensante e do pensado. Ela tem de mostrar em todo finito a finitude e, através da razão, de exigir a complementação (Vervollständigung) do mesmo." (HEGEL, 1970, 1, 422/423) Entretanto, paradoxal como possa parecer, é esta descrença na filosofia do entendimento que cria o ensejo para uma concepção de filosofia irredutível à reflexão. "Filosofia tem, enquanto reflexão, não somente seu limite na religião. Ela tem para esta uma função propedêutica." (JAESCHKE, 2010, 92) Em suma, ao término do período de Frankfurt, Hegel menciona que a "elevação do ser humano, não do finito ao infinito - pois estes são somente produtos

\footnotetext{
21 “Realmente ainda se fará necessário um tempo considerável de desenvolvimento sistemático para que Hegel tenha êxito em propor seu conceito "especulativo" não apenas como um critério contra uma compreensão "morta" de identidade, mas antes para transformá-lo, em ligação com o conceito de negação, num princípio de desdobramento das determinações lógicas - far-se-á necessário, sobretudo, o desdobramento do conceito de espírito enquanto conceito fundamental do sistema maduro." (JAESCHKE, 2010, 99-100)
} 
da simples reflexão, e como tais sua separação é absoluta -, mas antes da vida finita à vida infinita, é a religião." (HEGEL, 1970, 1, 421)

Depois disso, em Jena, Hegel alcança uma diferenciação mais nítida entre entendimento e razão, compreendendo-os como negatividade absoluta e positividade absoluta ${ }^{22}$. A partir disso, a razão preenche, enquanto reflexão filosófica, aquela pretensão de Hegel presente desde o Systemfragment: "a vida justamente não pode ser considerada somente como unificação, relação, mas sim tem, ao mesmo tempo, [de ser considerada] como contraposição" (HEGEL, 1970, 1, 422) - e que reaparece na Differenzschrift com a cláusula da cisão como "fator da vida" (HEGEL, 1970, 2, 21/22); preenchimento que, juntamente com a transformação da filosofia implicada em sua valorização frente à religião, constitui o genuíno berço da filosofia especulativa de $\mathrm{Hegel}^{23}$.

Sem dúvida, o resultado aparentemente frustrante, em torno do qual se estruturam as ideias de Hegel no Systemfragment e que revelam as dificuldades criadas pelo título escolhido por Nohl - a saber, justamente que a

\footnotetext{
${ }^{22}$ Tanto em Jena quanto no Systemfragment, Hegel concebe a filosofia de sua época como acometida pela oposição absoluta entre o que pensa e o que é pensado (HEGEL, 1970, 1, 423), entre sujeito e objeto. Assim como no último texto de Frankfurt, Hegel sustenta em Jena que a reflexão dilacera a absoluta unidade vital (HEGEL, 1970, 1, 422). "A reflexão isolada, enquanto pôr de contrapostos, seria um suspender do absoluto. Ela é a faculdade (Vermögen) do ser e da limitação." (HEGEL, 1970, 2, 26) O que se modifica substancialmente entre os dois períodos é justamente a concepção da verdadeira filosofia. "Suspender estas oposições tornadas firmes é o único interesse da razão. Este seu interesse não tem o sentido de que ela estivesse, em geral, se pondo contra a contraposição e a limitação." (HEGEL, 1970, 2, 21) Se a finitude da consciência tem de ser, enquanto ambiente da reflexão, não rechaçada, mas acolhida como momento insuficiente do absoluto, é a própria reflexão que tem de ser mostrada em sua referência positiva à reconstrução conceitual do mesmo: "a reflexão tem, enquanto razão, a relação ao absoluto e ela somente é razão através desta relação; a reflexão nadifica (vernichtet), nesta medida, a si mesma e a todo ser e limitado, ao relacioná-lo ao absoluto. Ao mesmo tempo, no entanto, justamente por sua relação ao absoluto, o limitado tem um subsistir." (HEGEL, 1970, 2, 26) O ponto de vista especulativo supõe a recondução da negatividade da reflexão ao absoluto enquanto ambiente em que os contrapostos adquirem subsistência e na qual têm sua origem: "a razão se põe contra a fixação absoluta da cisão pelo entendimento, e tanto mais [se opõe a essa fixação], quanto os opostos absolutos brotaram eles mesmos da razão." (HEGEL, 1970, 2, 21/22). Portanto, é a própria reflexão que "toma consciência" de si mesma como poder nadificador das oposições que ela própria engendra. "A razão se apresenta enquanto força do absoluto negativo e, com isso, como negar absoluto - e, ao mesmo tempo, como força da posição (Kraft des Setzens) da totalidade objetiva e subjetiva contrapostas. De uma vez, ela eleva o entendimento acima dele mesmo, impele-o, segundo a maneira dele, a um todo; ela o seduz a produzir uma totalidade objetiva." (HEGEL, 1970, 2, 26)

${ }^{23}$ “Todavia, Hegel chega com este pensamento tão próximo ao seu conceito tardio de dialética como em nenhum outro lugar em seus escritos de juventude, sem, no entanto, alcançá-lo. Pois as fontes conservadas dos escritos de Frankfurt não documentam mais o último passo, necessário para isso, que conduz da introdução pelo subjuntivo da fórmula "ligação da ligação e não-ligação" até sua reformulação no pensamento de uma filosofia "dialética", no princípio de uma identidade da identidade e da não-identidade." (JAESCHKE, 2010, 99).
} 
reflexão é incapaz de articular conceitualmente a totalidade viva em um sistema -, somente faz aumentar a dramaticidade que cerca a passagem do período de Frankfurt para o de Jena.

“A primeira filosofia propriamente técnica de Hegel é a sistematização reflexiva da impossibilidade de sistematizar, de reunir num todo, a vida livre, infinita (que constitui o ideal hegeliano) e a forma reflexiva de uma filosofia sistemática. Proclama a incapacidade da filosofia em produzir na unidade dos conceitos (pseudo-unidade da reflexão), unidade tão desejada que para Hegel então já estava dada na vida. Achava que a reflexão (recuo que põe à distância do ser e permite o retorno a ele, doravante posto) era um processo de objetivação, separação, oposição; de tal modo que refletir o ideal da juventude, isto é, a unidade das diferenças, é destruí-lo." (BOUR-

GEOIS, 1995, 386)

A conquista fundamental do Hegel impelido por estes questionamentos é justamente a ruptura com a compreensão analítica do conceito, a ruptura com o fascínio pelo conceito abstrato, a qual permitiria o amálgama de determinações contrárias em uma unidade conceitual cuja medida de abrangência é justamente seu poder de se erguer a partir da dilaceração absoluta. Finalmente, do ponto de vista do desenvolvimento do arcabouço lógico-especulativo que estrutura o sistema definitivo, o Systemfragment representa um momento intermediário entre o panteísmo centrado no conceito de amor - pelo qual Hegel descobre, na exigência de reconciliação dos opostos, as insuficiências do racionalismo tradicional -, e a formulação lógica da superação deste racionalismo. É verdade que no texto de 1800 não é ainda a lógica que arquiteta a integração dos opostos, e nisso Hegel permanece vinculado à atmosfera geral de crítica à racionalidade discursiva, tão significativa em sua época e cuja contrapartida é a reivindicação do caráter inefável da unificação absoluta, resistente ao escrutínio analítico do entendimento. Mas se é ainda ao espírito vivo que se concede a prerrogativa do acesso ao absoluto, à vida humana enquanto pode ascender à vida absoluta pela religião, no Systemfragment Hegel enuncia pela primeira vez, com clareza e com a abrangência que funda a reorientação especulativa, a síntese procurada nos anos de Frankfurt.

\section{Referências}

ADORNO, T. 1995. Progresso. In: ADORNO, T.W. Palavras e sinais. Modelos críticos 2. Petrópolis/RJ: Vozes.

BAUM, M. 1989. Die Entstehung der Hegelschen Dialektik. Bonn: Bouvier

BONDELI, M. 1997. Der Kantianismus des jungen Hegel. Die Kant-Aneignung und Kant-Überwindung Hegels auf seinem Weg zum philosophischen System. Hamburg: Felix Meiner. 
1999. "Vom Kantianismus zur Kant-Kritik. Der junge Hegel in Bern und Frankfurt," in: BONDELI \& LINNENWEBER-LAMMERSKITTEN. Hegels Denkentwicklung in der Berner und Frankfurter Zeit. München: Fink Verlag.

BOURGEOIS, B. 1986. A Enciclopédia das Ciências Filosóficas de Hegel. In: HEGEL, G.W.F. 1995. Enciclopédia das Ciências Filosóficas. São Paulo: Loyola.

DÜSING, K. 1969. Spekulation und Reflexion. Zur Zusammenarbeit Schellings und Hegels in Jena.In: Hegel-Studien 5. Hamburg: Meiner.

. 1994. Die Entstehung des Spekulativen Idealismus. In: JAESCHKE, W. Transzendentalphilosophie und Spekulation. Hamburg: Meiner.

2004. Gesetz und Liebe. Untersuchungen zur Kantkritik und zum Ethik-Entwurf in Hegels Frankfurter Jugendschriften.In MERKER, B. Subjektivität und Anerkennung. Frankfurt: Mentis.

GILBERT, G. 1982. Critique et dialectique : l'itinéraire de Hegel à Iéna, (1801 - 1805). Bruxelles: Facultés Universitaires Saint-Louis

HABERMAS, J. 1974. "Arbeit und Interaktion. Bemerkungen zu Hegels Jenenser 'Philosophie des Geites'". In: GÖHLER, G. Frühe politische Systeme. Frankfurt am Main: Ullstein, 1974.

2002. Discurso filosófico da modernidade. São Paulo: Martins Fontes.

HEGEL, G.W.F. 1988. Early Theological Writings. Tradução de T.M. Knox. Chicago: University of Chicago Press.

. 1966. Hegels Theologische Jugendschriften. Editado por Herman Nohl. Frankfurt: Suhrkamp. 1970. Werke in 20 Bände. Frankfurt am Main : Suhrkamp.

HONNETH, A. 1992. Kampf um Anerkennung. Zur moralischen Grammatik sozialer Konflikte. Frankfurt am Main: Suhrkamp.

ILTING, K-H. 1974. "Hegels Auseinandersetzung mit der aristotelischen Politik", in: Frühe politische Systeme. Gerhard Göhler, Frankfurt am Main, Ullstein. 759-785.

JAMME, C. 1988. Ein ungelehrtes Buch. Die philosophische Gemeinschaft zwischen Hölderlin und Hegel in Frankfurt 1797-1800, Bonn: Felix Meiner.

. 1990 “'Jedes Lieblose ist Gewalt'. Der junge Hegel, Hölderlin und die Dialektik der Aufklärung". In: JAMME, C. Der Weg zum System. Materialien zum jungen Hegel, Frankfurt am Main: Suhrkamp.

JAESCHKE, W. Hegel Handbuch. J.B. Metzler Verlag: Stuttgart, 2010.

KANT, I. 1968. Kants Werke - Akademie Textausgabe. Berlin: Walter de Gruyter.

KOTKAVIRTA, J. 2004. “Liebe und Vereinigung”. In: MERKER, B. Subjektivität und Anerkennung. Frankfurt am Main: Mentis.

LIMA, E. C. 2006. Direito e Intersubjetividade: eticidade moderna em Hegel e o conceito fichteano de reconhecimento. Campinas. 293 p. Tese de Doutorado em Filosofia, UNICAMP. 
LUKÀCS, G.1986. Der junge Hegel und die Probleme der kapitalistischen Gesellschaft. Berlin/Weimar: Aufbau-Verlag.

SIEP, L. 1974. Der Kampf um Anerkennung. Zu Hegels Auseinandersetzung mit Hobbes in den Jenaer Schriften“, in: Hegel-Studien 2, 155-209.

2000. Der Weg der Phänomenologie des Geistes. Ein einführender Kommentar zu Hegels "Differenzschrift" und "Phänomenologie des Geistes": Frankfurt: Suhrkamp.

WYLLEMAN, A. 1989. Driven Forth to Science, in: WYLLEMAN, A. Hegel on the ethical life, religion and philosophy (1793 - 1807). Louvain: Louvain University Press.

Endereço do Autor:

SQN 212, bloco A, apartamento 108.

CEP: 70864-010 Brasília - DF

callima_er@hotmail.com 